\title{
Insurer's Tort Liability for Issuing Policy Without Insurable Interest-A Comment
}

\author{
Richard W. Duesenberg*
}

The rule which requires an insurable interest in the object or person insured has more often than not been a benefit to the insurer than to the insured. It is the insurer who raises it in defense to an action to recover the proceeds, and who escapes liability if it is shown lacking. ${ }^{1}$ Not even a waiver of the requirement may be proved against the insurer. ${ }^{2}$ And not infrequently the insurer is permitted to keep the premiums collected on the policy.3 The want of insurable interest usually has been a matter of importance when a contractual obligation between the parties to the policy was being contested. Never until recently was it used to undergird a tort action against an insurance carrier. Thus it is of special interest that the first attempt to take the ingredient of insurable interest out of its contractual context and employ it im support of a tort action was successful.

The case in mind is Liberty Nat'l. Life Ins. Co. v. Weldon. ${ }^{4}$ An aunt purchased from the three defendant insurers separate policies on the life of her niece, naming herself as the beneficiary of the policies. Alabama law did not recognize an insurable interest in the aunt-mece relationship per se. 5 There being no financial interest in the continuance of the child's life, she neither living with nor being supported by the aunt, the latter was totally lacking in insurable interest. The policies were, therefore, void and unenforceable, a point conceded by all parties. The aunt then murdered the niece by feeding her arsenic. The aunt was executed. A wrongful death action $^{6}$ against the insurers was subsequently instituted by the father of the child, who predicated the case on the proposition that the acts of issuing

* Assistant Professor of Law, New York University; member, Missouri Bar.

1 Werenzinski v. Prudential Ins. Co. of America, 339 Pa. 83, 14 A.2d 279 (1940). Some courts have said that only msurers may raise the defense. Clements v. Terrell, $167 \mathrm{Ga} .237,145$ S.E. 78 (1928). Cf. Smith v. Coleman, 183 Va. 601, 32 S.E.. 2d 704, set aside on reheariug, 184 Va. 259, 35 S.E. 2d 107 (1945); Worthington v. Curtis, [1875] 1 Ch. Div. 419.

2 Patterson v. Durand Farmers Mut. Fire Ins. Co., 303 Ill. App. 128, 24 N.E.2d 740 (1940); Hack v. Metz, 173 S.C. 413, 176 S.E. 314 (1934). But cf. Wright v. Mutual Benefit Life Ass'n of America, 118 N.Y. 237, 23 N.E. 186 (1890).

3 The good faith of the applicant is important, recovery usually being allowed where the beneficiary acted in good faith. See Commonwealth Life Ins. Co. v. Wood, $263 \mathrm{Ky} .361,92$ S.W. 2d 351 (1936) ; Fisher v. Metropolitan Life Ins. Co., 160 Mass. 386, 35 N.E. 849 (1894). Statutes may affect the disposition of these funds. See N.Y. INs. Law \& 146(1).

4267 Ala. 171, 100 So.2d 696 (1957).

5 Commonwealth Life Ins. Co. v. George, 248 Ala. 649, 28 So. 2 d 910 (1947).

6 ATA. CoDE, tit. 7, § 119 (1940). 
these policies without ascertaining insurable interest were negligent conduct amounting to the proximate cause of the child's death. 7

There are two considerations: one, the matter of insurable interest; the other, the problem of foreseeability. While distinct, they are not separate.

Dealing first with insurable interest, the customary reasons given for the requirement in life insurance are twofold. Repeatedly the courts have said that "a contract of insurance upon a bife in which the insured has no interest is a pure wager that gives the insured a sinister counter interest in having the life come to an end." To minimize wagering and intentional homicide are the two announced objectives of the rule. Which of them more genuinely represents the policy behind the rule is on the surface no easy matter to decide, as the development of the law in this area reflects a seesawing for recognition as the superior policy for public concern. The fact is that the interest must be present, and when giving reasons, it has become bromidic for courts to say that without this interest the policy is a inere wager, promoting an interest in the early death of the insured.

Whether the recognition of one of the objectives to the exclusion of the other would restrict or extend the relationships within the insurable interest rule in any jurisdiction is not of concern here. However, when the concept of insurable interest is employed to support a tort action, the anti-wagering rationale is not very useful. Not so with the anti-homicide rationale. To say that the prevention of unlawful homicide is the purpose of the insurable interest rule is to set forth a premise which with perfect logic leads to tort liability on the part of a violating insurer. But to take these steps is to do something quite different from using the rule to declare a policy contractually void and unenforceable. Therefore, a brief refresher of the history of the rule is imperative to ascertain if the implied assumptions underlying it have any basis in fact.

The movement to declare void insurance policies lacking insurable interest was part of the on-going process of condemning wagering contracts generally. ${ }^{\theta}$ Before the intervention of legislation, gambling and wagering were not prohibited by Englisly law, this being essentially a concession to freedom of contract. It is apparent, however, from a long hine of cases that gambling was not respectable, and judges particularly criticized having to

7 The case has been noted favorably in 10 AxA. L. REv. 427 (1958), 19 O\#̈о ST. L.J. 532 (1958), 58 Coluar. L. Rev. 1087 (1958), and 63 Drck L. Rev. 172 (1959).

8 Grigsby v. Russell, 222 U.S. 149, 154 (1911). In property insurance, that it is necessary to measure the indemnity is often stated as a reason for the rule. Gorman's Estate, $321 \mathrm{~Pa} .292$, 184 Atl. 86 (1936).

9 The initial statute intended primarily to prevent gaming was An Act Against Unlawful Games, 17 EDw. IV, c. 3 (1477). The first to make unenforceable a wagering contract was An Act Against Deceitful, Disorderly and Excessive Gaming, 16 CAR. II, c. 7 (1664). Those dealing with insurance are given in notes 13 and 14 infra. 
hear and solemnly determine controversies of the utmost frivolity. 10 Eighteenth Century England witnessed a rapidly expanding foreign commerce, and consequently a vast accumulation of wealth. With investment opportunities somewhat limited, speculation caught fire in a rampant rage for gaming. Unscrupulous brokerage practices and much idle waste of time followed. Feverish and scandalous jobbing practices contributed directly to the splitting of Lloyds in 1769, for even this venerable establishment was not mimune to the contagion of the time.11 But one searches in vain the writings on that period for evidence that lives were endangered because of policies issued on them to others without interest.

That fortunes were dissipated taught its corrective lessons. The first legislative control of gaming under the guise of insurance was the British Insurable Interest Statute of 1746,12 which related to marine insurance. Thirty years later the statutory condemnation of wagering on human lives took form in the Life Insurance Act.13 Nothing is said in the statute or its preamble about an effort to minimize attempts to gain by committing unlawful homicides. Rather the reference is to a "mischievous kind of gaming," wherein the illnesses of prominent citizens, the elections of officials, or the trials of notorious criminals were made a matter of speculation. 14 It was specious moralizing in the famous case of Gilbert $v$. Sykes 15 for Chief Judge Ellenborough to rule unenforceable a policy on the life of Napoleon Bonaparte because it might affect the loyalty of the wagerer, or perhaps incite the French ruler to invade the island. And the rationale of other wagering cases 16 contributes to the reasonable conclusion that not murder, but wasted human effort and sharp jobbing practices were the targets of the insurable interest rule as an iinplementation of the antiwagering movement. 17

10 Hussey v. Crickitt, 3 Campb. 168, 170 Eng. Rep. 1343 (C.P. 1811) ; Brown v. Lceson, 2 H.Bl. 43, 126 Eng. Rep. 419 (C.P. 1792); Good v. Elliott, 3 T.R. 693, 100 Eng. Rep. 808 (K.B. 1790) ; Jackson v. Colegrave, Carth. 338, 90 Eng. Rep. 797 (K.B. 1695) ; Pope v. St. Leger, 1 Salk. 344, 91 Eng. Rep. 301 (K.B. 1694). In DaCosta v Jones, 2 Cowp. 729, 735, 98 Eng. Rep. 1331, 1334 (K.B. 1778), Mansfield, C.J., said "this species of contract has, in fact, gone to an extent that is much to be complained of ...."

11 Straus, Lloyds-The Gentremen at the Coffee-House 87-92 (1938); Worsley \& GrifFith, The Romance of Lioyds 125-131 (1936); Wright \& FayLe, History of Lloyds 88-99 (1928).

1219 GEO. II, c. 37, $\$ \$ 1,2$, (1746).

1314 GEo. III, c. 48 (1774). This statute was also applicable to fire insurance or "any other event."

14 See note 11 supra.

1516 East. 150, 104 Eng. Rep. 1045 (K.B. 1812).

16 See note 10 supra.

17 "[I]ndeed, the ground of the objection to hife insurance without interest in the carlier English cases was not the temptation to murder but the fact that such wagers came to be regarded as a mischievous kind of gaming." Grigsby v. Russell, 222 U.S. 149, 156 (1911). 
Nevertheless, as time went by, courts stated again and again that protection of human lives was the reason for the rule. Without any proof that a wagerer would be more prone to kill than many who might meet the test of insurable interest, without any analysis of the history of the insurable interest statutes, we find such sweeping statements as the following, relied upon by the court in the Weldon decision: ${ }^{18}$

[W] ager policies, or such as are procured by a person who has no interest in the subject of insurance, are undoubtedly most pernicious in their tendencies, because in the nature of premiums upon the clandestine taking of human life....

The reason of the law which vitiates wager policies is the pecuniary interest which the holder has in procuring the death of the subject of insurance, thus opering a wide door by which a constant temptation is created to commit for profit the most atrocious of crimes.

A good number of opinions have similarly ascribed to the anti-crime objective first consideration in analyzing the insurable interest rule. How baseless this is in historical perspective has just been indicated. Furthermore, how wide can the door to temptation be, in view of criminal sanctions and the rule that a inurderous beneficiary cannot benefit from his acts, a rule which the criminal unay not be presumed to know, but about which he might be said to have some feeling? Of course, the argument is made that the wagerer-criminal does not expect to be caught. That is probably more hope than expectation, and is not responsive as an answer to the preceding historical objections to the anti-homicide reason for the rule.

There are other objections to the repeated use of the anti-inurder rationale for insurable interest. A Maryland court once enunciated dissatisfaction in these words: 19

In some American cases they [policies without interest] have been denounced as void, not simply because they tend to promote gambling, but because they are incentives to crime. The force of this latter suggestion has been, and may well be, doubted. It means that one not related or connected by consanguinity or marriage, who may have a direct pecuniary interest in the speedy death of another, will thereby be tempted to inurder him, though le knows that lianging is the penalty for such a crime. This doctrine, carried to its logical result, has a far-reaching effect. It strikes down every legacy to a stranger which may become known to the legatee, as is fre quently the case, before the death of the testator. It inakes void every similar limitation in remainder after the death of a life tenant. Every like conveyance of property in consideration that the grantee shall support the grantor during his life, falls under the same condemnation. Yet we know of no case in which a Court has declared such testamentary dispositions or conveyances to be void on this ground. 
Professor Patterson has rightly pointed out a deficiency in this line of reasoning. ${ }^{20} \mathrm{He}$ called attention to the fact that the above mentioned legal devices are all vountary commitments by him whose early death is made a matter of financial increment to another. The element of gratuity is said to preserve from invalidity an insurance policy taken out by the cestui que vie in favor of a beneficiary without insurable interest. Then, too, there is the well-established rule that a creditor has an insurable interest in the life of his debtor. If the anti-homicide motive for the insurable interest rule were the principal policy concern, it is hard to imagine how this rule could have been estabhished. Creditors have not been traditional bedfellows of debtors, and many might fall into Holmes' undefined category of the "world of the unscrupulous." 21 Why this group is said to have an insurable mterest can be understood only in the perspective of the antiwagering analysis of the insurable interest requirement.

What has been said so far is not written to deny that the motive for gain is ever a partner in criminal intent. It is intended to support the writer's contention that a violation of the insurable interest rule should not result in actionable negligence, either per se or prima facie. More about that a little farther on. For the moment, let: us look to the logic of the Weldon opinion. In the words of the court, it is as follows: 22

[A]ll negligence is not actionable. To be actionable it must be the breach of a duty which the defendant owed the plantiff as an individual or one of a class ... and the plaintiff must not only show causal connection between the negligent breach of the duty but that such negligence was the proximate cause of the injury.

This extract from the case correctly states the syllogism of tort liability. But wliat so many general propositions lack is lacking in this one also. That is, when is there a duty? Whenever it is stated that the breach of a duty may give rise to an action for damages, the overriding question to determine is the existence of a duty. The court apparently finds this duty in the alleged danger placed on one whose life is the subject of a wager policy, which situation the court says finds legislative response in the statute declaring void a policy without insurable interest. It is interesting here to note that since there was a violation of a statute, the court might have said that the violation was negligence per se and the proximate cause of the injury.

Finding culpable negligence in the violation of a statute, without an $a d$ hoc consideration of causal connection, is the approach of a few courts. ${ }^{23}$

20 Patterson, Insurable Interest in Life, 18 Corus. L. REv. 381, 390 (1918).

21 Grigsby v. Russell, 222 U.S. 149 (1911).

22267 Ala. at 185,100 So. $2 \mathrm{~d}$ at 707.

23 The ignition key cases are in point. Ostergard v. Frisch, 333 Ill. App. 359, 77 N.E. 2d 537 (1948), noted in 23 IND. L.J. 494 (1948) ; Ross v. Hartman, 139 F.2d 14 (D.C. Cir. 1943), noted in 32 GEo. L.J. 202 (1944). 
More commonly violation of a safety statute is viewed as negligence, but also needed for recovery is a showing of proximate cause, i.e., that the prohibited event really caused the injury. ${ }^{24}$ When an intervening criminal act is also present the difference in handling, i.e., whether the court will require a showing of actual causation and not merely violation of a statute, is crucial to the interests of the defendant.

Legal causation did have to be proved in this case. The insurers contended that the "separate, independent, superseding, wilful, malicious, crime of murder 25 became the responsible cause of the death" 26 of the child. This defense of interveming crime plunged the court into the problem of proximate cause. But it did not dip deeply. Nor was it necessary to, for if minimizing nurder were truly the purpose of the insurable interest rule a breach of the rule certainly would result in tort responsibility in spite of the intervening crime. The court used familiar language:27

If the act of the intervening agency could have been reasonably foreseen the causal chain is not broken. But if the injury results from an independent, intervening, efficient cause, not reasonably to be anticipated, to wit, the act of a third person, the negligence shown, if any, is not the proxinuate cause of the injury.

And further on:28

But intervening criminal acts may be found to be foreseeable and, if so found, actionable negligence may be predicated thereon.

It is not surprising, then, that when the question of proximate- "legal"-cause was given to the jury, it was found to be present in the sequence which led to the death of the child. Once the basic premise was stated, no appreciable expectation of avoiding liability because of intervening crime existed. This defense was rather feeble. Writers have said that extended tort responsibility is a matter of policy 29 and courts have agreed that changing times require changing applications of the concept of proximate cause and foreseeability. 30 Sounding the end of the insurer's hope for non-liability was the very important assumption that because issuing a policy without insurable interest created a danger to the insured

${ }^{24}$ Sullivan v. Griffin, 318 Mass. 359, 61 N.E. 2d 330 (12945). The court said that to make violation of a statute of itself culpable negligence without inquiring into causation would go far toward making the violators insurers of public safety. The potential scope of the Ross $v$. Hartman decision, note 23 supra, has been limited considerably, if indeed, not reversed. See Hecht Co. v. McLaughlin, 214 F.2d 212 (D.C. Cir. 1954); Peigh v. Baltimore \& O.R.R., 204 F.2d 391 (D.C. Cir. 1953).

25 For the case affirming the conviction of the aunt for murder, see Dennison v State, 259 Ala. 424,66 So. 2d 552 (1953).

26267 Ala. at 186,100 So. $2 d$ at 709.

27 Id. at 187,100 So. $2 \mathrm{~d}$ at 709 .

${ }^{28}$ Id. at 188,100 So. $2 \mathrm{~d}$ at $710-11$.

28 Feezer, Intervening Crime and Liability for Negligence, 24 MrN. L.R. 635, 642 (1940).

${ }^{30}$ Szabo v. Tabor Ice Cream Co., 37 Ohio App. 42, 174 N.E. 18 (1930). 
life, there was a duty not to issue it, or at least to exercise due care to ascertain whether the interest existed:31

Does a life insurance company have the duty to use reasonable care not to issue a policy of life insurance in favor of a beneficiary who has no interest in the continuation of the hife of the insured?

No case has come to our attention where this specific question has been considered by any court. But we are of the opinion that such a duty exists, for there is a duty upon all to exercise reasonable care not to injure another....

As we have shown, it has long been recognized by this court and practically all courts in this country that an insured is placed in a position of extreme danger when a policy of insurance is issued on lis hife in favor of a beneficiary who has no insurable interest. There is no legal justification for the creation of such a risk to an insured and there is no social gain in the writing of a void policy of insurance. Where this court has found that such policies are unreasonably dangerous to the insured because of the risk of inurder and for this reason has declared such policies void, it would be an anomaly to hold that insurance companies have no duty to use reasonable care not to create a situation which may prove to be a stimulus for murder.

The interesting point here is the court's remark that it has found wagering policies to be dangerous. In tracing through previous Alabama insurable interest cases, not one was discovered where this finding was shown to be true. Weldon is the first case in that jurisdiction of a murderous beneficiary who had no insurable interest. There simply is no demonstrable proof that "an insured is placed in a position of extreme danger where a policy of insurance is issued on his life in favor of a beneficiary who has no insurable interest." Indeed, not a few cases may be found where the murderous beneficiary did have an insurable interest. It is the presence of the insurable interest to which the oft-invoked inurderous beneficiary rule owes its existence, for the absence of the element of interest would be sufficient grounds of itself for non-liability. Furthermore, no similar duty has ever before been imposed by either English or American courts during the nearly 200 years existence of the insurable interest rule, and while there is nothing improper in establishing new duties, when doing so the court should at a mimimum examine the past to illumine the present. If this had been done, the fanciful nature-that it is predicated on theoretical arguments espoused in vacuo and not in the light of social experience- of the reason for insurable interest so much relied on might have been uncovered.

One of the defensive arguments of the insurers was that it would be an "impossible burden" to investigate the applicant-beneficiary's insurable interest. To this, the court answered rhetorically:32 
Why is it any more of an "impossible burden" to require an insurance company to exercise reasonable care to determine whether the beneficiary has an insurable interest in the insured before it issues the policy of insurance than after the insured [cestui que vie] is dead?

This on the surface appears to be a reasonable reply. If estoppel were being pleaded against the insurer's defense of no insurable interest, in an action for either the face value of the policy or for return of paid premiums, it would have much appeal, particularly in the latter of the suggestions. What it overlooks, however, is that insurable interest is not always easily determinable, a fact which the same court in a previous occasion conceded. ${ }^{33}$ Statutes and cases vary from jurisdiction to jurisdiction, and in Alabama no statutory guide is available to an insurer. ${ }^{34}$ True, there had been a previous case 35 which ruled that relationship alone, and more especially the aunt-niece relationship, would not be sufficient insurable interest. The insurers might be presumed to know this. But if one surveys the vast bulk of cases through the decades of this century and the last, the diminution in requirements for insurable interest in life is easily perceived.36 This progress is largely the result of judicial shifts in attitude. But in each instance of a change, a policy had first to be issued. Under the fears of this type of decision, carriers may well think twice before insuring. What other cases have achieved in augmenting the social and economic utility of insurance may well be cancelled out by an ill-considered opinion such as this. 37

33 "What will constitute an insurable interest in the life of another, such as will rescue such contracts from the imputation of being regarded as wager policies, it is not easy to define by a general rule. It has been held, in some cases, that the interest must be, in some sense, a pecuniary one, not predicated merely upon the fact of existing relationship.... In other cases, a contrary view has been intimated, which does not, however, seem to be sustained by the weight of authority." Helmetag's Adm'rx. v. Miller, 76 Ala. 183, 187, 52 Am. Rep. 316, 317 (1884).

34 The Alabama code merely states that an insurable interest is required for an insurance policy. AIA. CODE, tit. 28, § 2 (1940). The problems of legislative drafting are reflected in the words chosen to define insurable interest in the New York statute: "The term, "insurable interest', as used in this section, shall mean: (a) In the case of persons related closely by blood or by law, a substantial interest engendered by love and affection; and (b) in the case of other persons, a lawful and substantial economic interest in having the life, health or bodily safety of the person insured continue, as distinguished from an interest which would arise only by, or would be enhanced in value by, the death, disablement or injury, as the case may be, of the person insured." N.Y. INs. LAW § 146(2). Insurable interest in property is defined as any "lawful and substantial economic interest in the safety or preservation of property from loss, destruction or pecuniary damage." N.Y. INs. LAW $\$ 148$.

35 Commonwealth Life Ins. Co. v. George, 248 Ala. 649, 28 So. $2 d 910$ (1947).

30 This is true of interests deemed "insurable" in both life and property insurance. Two outstanding articles which point up this development are Patterson, Insurable Interest in Life, 18 Coluar. L. Rev. 381 (1918), and Harnett and Thornton, Insurable Interest in Property: $A$ Socio-Economic Reevaluation of a Legal Concept, 48 CoruM. L. REv. 1162 (1948).

37 The rationale of the Weldon case is equally applicable to property insurance policies. Therefore, investigation of the moral character of the applicant will assume greater importance, and insurers may prefer not to issue policies if insurable interest is not clearly present. It is only 
Since the range of interests embraced in the concept of "insurable" is so indeterminate, the point made by the insurers is very important. A search for an answer which does not exist is not only frustrating, but frightening when the penalty of action taken may be a judgment for tens of thousands of dollars. 38 Nor can it be much consolation to insurers that under the Weldon decision their only duty is to use "reasonable" care to learn of an insurable interest. "Reasonable" is generally viewed as peculiarly in the domain of a jury's intelligence, and an insurer's prospect of finding itself faced with a jury as decision-maker is a situation from which it may well recoil.

If the Weldon case had been one of first impression on the relationship involved, it is interesting to speculate whether liability could have been imposed. Assuming the court would retain its position that there existed the duty to use reasonable care, to breach the duty and incur liability would require some doing, unless the court is willing to say that not to breach a duty which is undefinable is itself a duty. If this position were taken, would liability be dependent on whether the breach was informed or uninformed, i.e., with knowledge that investigation would yield no determination of the insurable nature of the particular interest, or a mere failure to inquire? $\mathrm{Ob}$ vious conflicts of laws problems also present theinselves. In Arkansas the aunt-niece relationship is within the scope of insurable interests. If the policies of the Weldon case had been issued to the aunt in Arkansas, she being a citizen of that state, and all other facts had been the same, could the father have recovered judgment in an Alabama court, assuming jurisdiction over the imsurers?

The answer to the conflicts hypothetical would seem to be negative, for the breach of insurable interest, a crucial ingredient of the Weldon decision, is absent from the facts. It is beyond the scope of this comment to conduct an analysis of the conflicts problems presented. The example, however, again serves to demonstrate the utter inapplicability of insurable interest to the kind of liability imposed in the decision. Whether insurable interest is present or not simply does not affect the creation, if such there be, of a danger to the cestui que vie..$^{39}$ Any danger created flows not from a breach of the insurable interest rule, but from the beneficiary's preference for the

a short step from the Weldon decision to imposing liability $m$ tort on an insurer of property for issuing a policy for full value of the property to one with a limited interest therem. The Weldon decision has implications of enormous proportions for the business of life and property insurance.

38 In the Weldon case the judgment was for $\$ 75,000$. The aggregate value of the policies was $\$ 6500$.

39 Note the bizarre implications of the court's contention that to issue a policy without insurable interest opens wide the door to the crime and puts the life insured in extreme danger. One is that states im which the range of interests deemed insurable is greater than other states, to the extent that it is greater, encourage the temptation to commit crime. 
proceeds of the policy over the continuance of the insured's life without relation to the insurable interest. ${ }^{40}$ Recognizing this, not only is the theory of the action brought in this case ruled out, but a court, if it is to allow an action in tort against an insurer for issuing a policy on the life of another, must do so on this ground: that to issue policies to applicants who theinselves are not the cestui que vie creates a potential danger to the insured life, and that reasonable care must be exercised by insurers not to create this danger. Of course, no court has ever taken this position, and it is clearly inconsistent with reality.

Compared to the insurable interest approach of the Weldon decision, the suggestion of a "consent" approach has on its surface some practical merit. To illustrate, the reasonable care necessary to avoid creating a danger to another could take the form of procuring the consent of the cestui. All the problems of what falls within the pale of insurable interest are avoided. ${ }^{41}$ Unless, of course, the insurer had reason to know of the applicant's intent to kill, the consent of a cestui would operate to relieve the insurer of any liability if a danger were in fact created, a kimd of contracting away of liability. The suggestion is not free of difficulties, most apparent being those which would arise if the cestui is incompetent to contract. This would include minors and incompetents. As parents give consent to surgery for a child, so their consent in this context might also be the solution. But if the applicant whose legal consent is required is also the one contemplating injury to the insured life, the consent given may well be defective. True, no action would lie in favor of the applicant-beneficiary-parent, and if the cestui were dead, problems would not arise. But there is nothing in the Weldon analysis which requires death to occur for there to be actionable negligence. Injury without death may be enough. Could the child now sue, alleging the incompetent consent of the scheming parent? It would seem obvious that the answer is negative, but it may be well advised for insurers to make efforts to get statutory clarification of what their due care requires.

I think it is clear that the Weldon decision is very important. It has tremendous implications for insurers. That the floodgates of litigation may have been opened is not a valid criticism, however great the deluge, if opened they ought to be. Nonetheless, the insurable interest approach seems to this writer preposterous.

40 The objection cannot be made here that if there is insurable interest, and death occurs, there is no gain. Life insurance, unlike property, is not primarily an indemnity contract. And further, if there is no interest in the continuance of the life, but rather a desire to get the proceeds of a poicy on it, it is incorrect to talk in terms of indemmity.

41 See notes 32-36 supra and accompanying text. 